DOI: https://doi.org/10.24127/ajpm.v9i4.3138

\title{
ANDROID-BASED MOBILE LEARNING APPLICATION AS A LEARNING EXERCISE FOR STUDENTS
}

\author{
Ayu Faradillah ${ }^{*}$, Diar Fadilah ${ }^{2}$ \\ ${ }^{1,2}$ Department of Mathematics Education, Universitas Muhammadiyah Prof. DR. HAMKA, \\ Jakarta, Indonesia. \\ *Corresponding author. Jl. Tanah Merdeka No.20, Rambutan, Ciracas, Jakarta Timur \\ E-mail: $\quad$ ayufaradillah@uhamka.ac.id ${ }^{\left.{ }^{*}\right)}$ \\ diarfadilah98@gmail.com $^{21}$
}

Received 04 October 2020; Received in revised form 10 December 2020; Accepted 27 December 2020

\begin{abstract}
This study aimed to develop a mobile learning application as a learning exercise for students in Mathematics learning. The research method used was the Research and Development (R\&D) with a Four-D (4D) development model. This study utilized a questionnaire to analyze students' needs for mobile learning applications in Mathematics learning, which was filled out by 101 students. The analysis was performed using the Rasch Model. The results of the analysis show that students need applications to help the learning process such as collecting assignments that can be done anywhere and at any time as well as features equipped with mathematical symbols to smooth the discussion with teachers and classmates. Therefore, the design of the mobile learning application developed has a database that is divided into 2 local hosts, including those for teachers and students. The database can connect teachers and students, and students can complete assignments anytime and anywhere, and write mathematical symbols. Based on the results of the study, the Cadudasa mobile learning application received a feasibility assessment by media experts with a percentage of $84 \%$ in the good category. Student responses to the Cadudasa mobile learning application were $86 \%$ in the very good categories. The results of this study indicate that the Cadudasa mobile learning application is considered appropriate to being used as a medium of learning in schools
\end{abstract}

Keywords: android application; learning exercise; mobile learning; Rasch model

\begin{abstract}
Abstrak
Penelitian ini memiliki tujuan untuk mengembangkan aplikasi mobile learning sebagai learning exercise bagi siswa dalam pembelajaran matematika. Metode penelitian yang digunakan adalah Research and Development $(R \& D)$ dengan model pengembangan Four-D (4D). Penelitian ini menggunakan angket analisis kebutuhan siswa terhadap aplikasi mobile learning dalam pembelajaran matematika dimana total siswa yang mengisi angket sebanyak 101 orang. Analisis dilakukan dengan menggunakan Rasch Model. Berdasarkan hasil analisis diperoleh bahwa siswa membutuhkan aplikasi yang dapat membantu proses pembelajaran seperti pengumpulan tugas yang dapat dilakukan dimanapun dan kapanpun serta adanya fitur simbol-simbol matematika yang memudahkan untuk berdiskusi dengan guru dan teman sekelasnya. Sehingga, desain aplikasi mobile learning yang dikembangkan memiliki database yang dibagi menjadi 2 localhost yaitu untuk guru dan siswa, database tersebut dapat terkoneksi anatara guru dan siswa, kemudian siswa dapat menyelesaikan tugas dengan waktu kapanpun dan dimanapun, dan dapat menuliskan simbolsimbol matematika. Berdasarkan hasil penelitian, aplikasi mobile learning Cadudasa mendapatkan penilaian kelayakan oleh ahli media dengan persentase $84 \%$ dengan kategori baik. Respon siswa terhadap aplikasi mobile learning Cadudasa mendapatkan hasil 86\% dengan kategori sangat baik. Hasil penelitian ini menunjukan bahwa aplikasi mobile learning Cadudasa dinyatakan layak untuk dijadikan sebagai media pembelajaran di sekolah.
\end{abstract}

Kata kunci: Android applications; learning exercises; mobile learning; Rasch models

This is an open access article under the Creative Commons Attribution 4.0 International License 
DOI: https://doi.org/10.24127/ajpm.v9i4.3138

\section{INTRODUCTION}

A review of some relevant research reveals the potential benefits and challenges of using mobile devices in learning. Some of the benefits of using mobile learning technology include; (a) there are no barriers to geographic boundaries because learning can occur anywhere and at any time, (b) help students develop didactic self-centered learning, (c) facilitate efficient communication mechanisms for discussion in learning and to support and review content between teachers and students (Kumar \& Mohite, 2018). Mobile learning is learning that is performed through the utilization of a mobile device like a PDA (Personal Digital Assistant), cell phone, portable video player, Tablet PC, or other devices that can connect to the internet (LavinMera et al., 2010). Mobile learning can be utilized to develop learning pedagogy that can be applied in various environmental contexts and subject area contexts with internet connectivity (Crompton, 2017). At present, the use of mobile learning can fill the gap of traditional learning through its special features (Başaran \& Haruna, 2017). Mobile learning can also facilitate the learning process and improve students' interest in learning along with the change in learning styles from conventional to modern learning (Lynnette \& Cabanban, 2013).

Currently, mobile learning is widely known among academics because it can carry out daily learning and tasks more flexibly and comfortably. Various educational institutions have implemented mobile learning globally to deliver learning anytime and anywhere in different ways. (Al-Emran et al., 2016). Teachers and students can provide and complete learning tasks in a short duration using mobile learning (Al- hunaiyyan et al., 2017). And, based on the research it is known that students who get learning using e-learning media with the guided discovery method have an average score of learning independence that is superior to students who only get learning using the guided discovery method (Lu'ulilmaknun \& Wutsqa, 2018).

Some previous studies have been conducted on the development of mobile learning applications, such as research conducted by Chung and Khor on developing and implementing Mobile Learning Initiatives through the Mobile Learning Research Group (MLRG) to provide distance learning experiences at WOU (Wawasan Open University) (Chung \& Khor, 2015). Furthermore, a study was conducted by Calimag et al. regarding the application of the Ubiquitous learning atmosphere using a mobile learning application (Calimag et al., 2014). Besides, a study was conducted by The Family Math Project Team on developing the Go Math! for solving Mathematics problems (Alexander et al., 2010). Then, Rachmawati et al. conducted a study about developing a mobile learning application based on character education with a contextual approach to vocational students (Rachmawati et al., 2020).

Those relevant studies obtained research results in the form of a WOU mobile learning application that aims to provide real-time interactive learning (Chung \& Khor, 2015). Furthermore, Calimag developed an application by applying the ARCS (Attention Relevance Confidence Satisfaction) learning model to encourage and maintain student motivation to learn (Calimag et al., 2014). Meanwhile, Go Math! application implements a game and a story to provide the impression of fun and interesting Mathematics 
learning. This application was developed to support students in solving Mathematics problems related to daily activities in the family environment (Alexander et al., 2010). The study conducted by Rachmawati et al., (2020) generated the Math-Cha mobile learning application which consists of material and evaluation by integrating character education and is presented contextually to support the revitalization of vocational education. Based on the relevant studies above, no research has developed and utilized mobile learning as a learning exercise for students that can be carried out flexibly and not limited by time and space, As well as the analysis conducted by the research, the fact that students find it difficult to deduce in solving math tasks remotely.
This study focused on developing mobile learning media based on the Android operating system which is utilized to access distance learning. This research aimed to develop mobile learning application features to facilitate remote learning exercises.

\section{METHOD}

This type of study was Research and Development. The model used was the development of the 4D (Four-D) model consisting of four main stages, including: Define, Design, Develop, and Disseminate. (Thiagarajan, 1974). In this study, the research and development process only through three stages, there are define, design and develop. A description of the model is presented in Table 1.

Table 1. The stages of the 4D development model.

\begin{tabular}{|c|c|c|}
\hline No & Stages & Definition \\
\hline 1 & Define & $\begin{array}{l}\text { Activities to determine and define needs in learning activities to } \\
\text { collect various kinds of information associated with learning } \\
\text { media, including initial analysis, student analysis, concept } \\
\text { analysis, and analysis of learning objectives. }\end{array}$ \\
\hline 2 & Design & $\begin{array}{l}\text { Activities to make design of mobile learning application that will } \\
\text { be developed. This activity includes selecting media, appropriate } \\
\text { format and make an application design. }\end{array}$ \\
\hline 3 & Develop & $\begin{array}{l}\text { Activities to create and produce media, that later is subjected to } \\
\text { validation tests by experts and followed by product improvements. }\end{array}$ \\
\hline 4 & Disseminate & $\begin{array}{l}\text { Activities to instructional materials reach their final production } \\
\text { stage hen developmental testing yields consistent results and } \\
\text { expert appraisal yields positive comments. }\end{array}$ \\
\hline
\end{tabular}

The location of the research is SMAN 106 Jakarta. The research subject were 40 students class $\mathrm{X}$ and XI. The instruments used in this research were expert validation sheets and questionnaire responses of students towards the mobile learning application. The data obtained were quantitative and qualitative. Quantitative data were the scores obtained from the validator and students, which were ranged on a scale from 1 (strongly disagree), 2 (disagree), 3 (agree), and 4 (strongly agree) (Rachmawati et al., 2020). Meanwhile, qualitative data was in the form of errors, suggestions, and comments. The results of the assessment from expert validation were used as the basis for product improvement before being tested. Furthermore, the results of the 
questionnaire responses of the students were used to determine the feasibility of the developed Android-based mobile learning. The results of the expert validation test and student responses were calculated using the average score formula (1).

$$
P=\frac{f}{N} \times 100 \%
$$

$P$ is the percentage value, $f$ is the result of a per-indicator assessment, dan $N$ is the maximum value per indicator (Amirullah \& Susilo, 2018), which is then categorized in accordance with the interpretation. The percentage ranges of the results of the validity and feasibility tests are presented in Table 2.

Table 2. The percentage range and category of mobile learning.

\begin{tabular}{ccc}
\hline No & $\begin{array}{c}\text { Percentage } \\
\text { Range }\end{array}$ & Category \\
\hline 1 & $85 \%<P \leq 100 \%$ & Very good \\
2 & $75 \%<P \leq 85 \%$ & Good \\
3 & $60 \% \leq P \leq 75 \%$ & Fair \\
4 & $P \leq 59 \%$ & Not good \\
\hline
\end{tabular}

\section{RESULTS AND DISCUSSION}

The results of the development research that had been conducted to develop and generate an android-based mobile learning application called Cadudasa have several steps taken, including define, design, and develop which are described as follows.

\section{Define}

In the stage of define, several analyzes were performed including initial analysis, student analysis, concept analysis, and analysis of learning objectives. The initial analysis was done by conducting observations and interviews with the vice-principal, Mathematics teachers, and students at State Senior High School (SMAN) 106 of Jakarta. The observations and interviews show that the learning method remained using conventional learning and did not utilize existing learning media. The learning media used by teachers have mostly printed books and Microsoft PowerPoints, while for assignments and examinations, SMAN 106 Jakarta sometimes used SiPintar media developed by the Education Office. The use of SiPintar e-learning requires a computer or laptop with an internet network to maximize working on the assignments. In addition, the results of interviews with students show that most of students collected assignments via e-mail or directly to the teacher. The previous research shows that the use of mobile learning in conventional learning can make learning time more flexible and make it easier to collect assignments (Astuti et al., 2019). The use of mobile learning in mathematics learning greatly affects student learning outcomes, Research that has been conducted to measure the effectiveness of learning using mobile learning has resulted in $85.94 \%$ positive results and $84.38 \%$ of students feeling motivated (Nasir \& Nirfayanti, 2019). The main purpose of enabling learning using mobile learning is education, instead of entertainment, and not all about the presentation of the media (Calimag et al., 2014). Therefore, it is necessary to develop learning media that can assist and combine the distant processing and collection of tasks in the form of an Android-based mobile learning application, in addition to providing new methods and atmosphere in the learning process. (Grant, 2019).

Student analysis was carried out to determine students' needs in the use of learning media of android-based mobile learning. The researchers distributed a questionnaire instrument that consisted of 24 statements and divided into 3 
indicators to 101 students in SMAN 106 of Jakarta. The data were analyzed using the Rasch Model (WinSteps). Rasch Model was used to produce relevant statistical analysis which provided information to the researchers on the problems data obtained to compile and evaluate (Azka \& Faradillah, 2020; Rahayuningdewi \& Faradillah, 2020). The assistance of WinSteps software produced Rasch output that was consistent and accurate (Hadi \& Faradillah, 2019). The results of the
Rasch output model in this study is shown in Figure 1. The figure show subjects' scores and the relative difficulty of items on calibrated Rasch scales. The left side of the plot shows the participants' responses, while the right side of the plot shows the item difficulty level. The highest peak shows the highest level of participation by the respondent on the most difficult statement items and the lowest participation rate is shown at the bottom of the plot (Lamb et al., 2012).

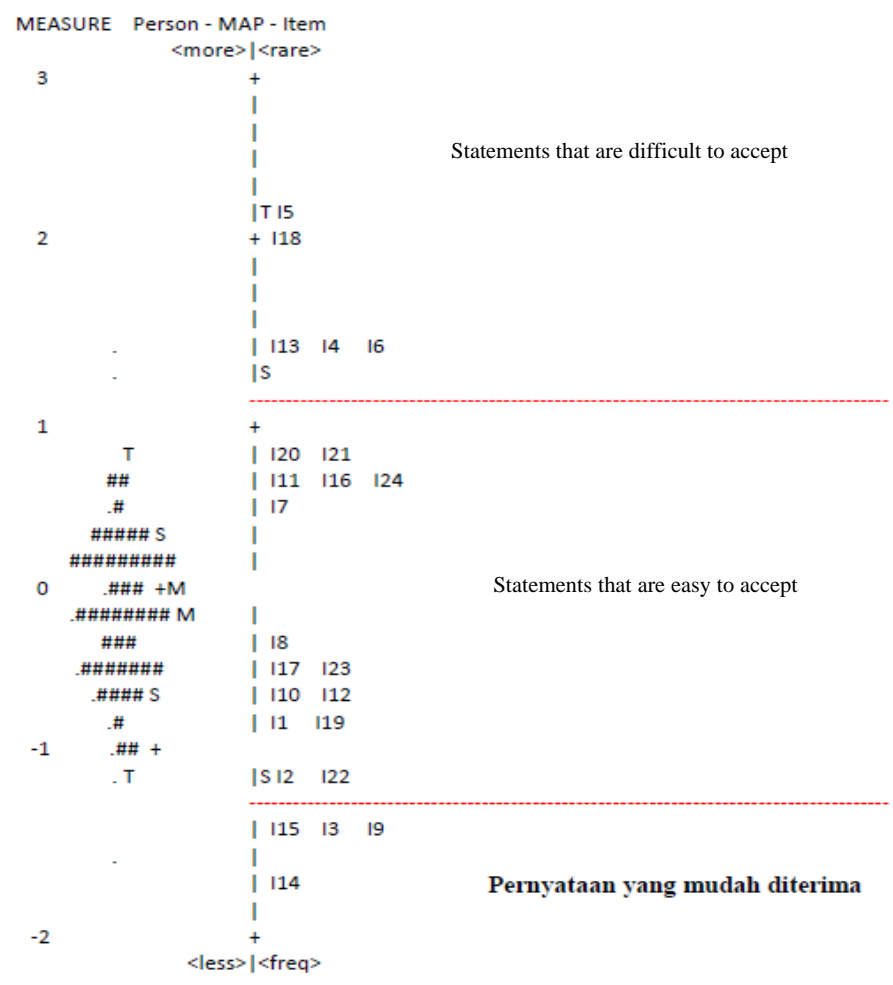

Figure 1. Wright-maps of students' need analysis.

The results of the analysis show that the statements that did not show student interest in mobile learning were I5, which was a statement that students are more interested in completing the task by having a direct discussion. Students felt difficulty in completing assignments remotely or using learning media. They felt difficult to discuss and communicate directly with their teachers and classmates. The ease of communication on mobile learning can facilitate more active interactions between teachers and students (Kim et al., 2013). Meanwhile, the statement showing that students need mobile learning in learning was I14, stating that the addition of the function of mathematical symbols can help students to communicate with teachers and classmates easily, as communication is 
essential in a learning process (Parvez et al., 2019).

Concept analysis was performed by observing and analyzing several existing learning media that are used in learning with the principles of ATM (Observe, Imitate, and Modify). One of the analysis of learning objectives was to meet the students' needs to use Androidbased mobile learning media. The learning media developed was expected to be able to assist students and teachers to complete assignments anywhere and anytime, as well as facilitate remote Mathematics learning (Calimag et al., 2014; Erkollar \& Oberer, 2012; Kearney \& Maher, 2013).

\section{Design}

This stage serves for designing the mobile learning application that was developed. The application was developed based on the results of student analysis to develop applications that suit their needs and usability. Mobile learning development must be based on the principles and provide solutions to existing problems by developing a mobile learning application as a solution to these problems (Calimag et al., 2014;
Khanghah et al., 2012). The mobile learning application developed was made based on the needs of the learning process (Chung \& Khor, 2015). The features contained in the mobile learning application such as in this Android-based mobile learning application called Cadudasa was designed to have a database that is divided into 2 localhosts, which is for teachers and students. The database can connect teachers and students as well. This connectivity enables collaboration between teachers and students (Kearney \& Maher, 2013). This mobile learning application also has features that can generate assignments, material, and answers, in the form of documents and figures. Questions and material can be accessed by students and they can upload the answers to the assignments. In this application, the teacher can also review the results of student assignments and provide the scores.

The home menu display for selecting teacher and student sections, as well as the teacher's view for creating assignments, are presented in Figure 2.

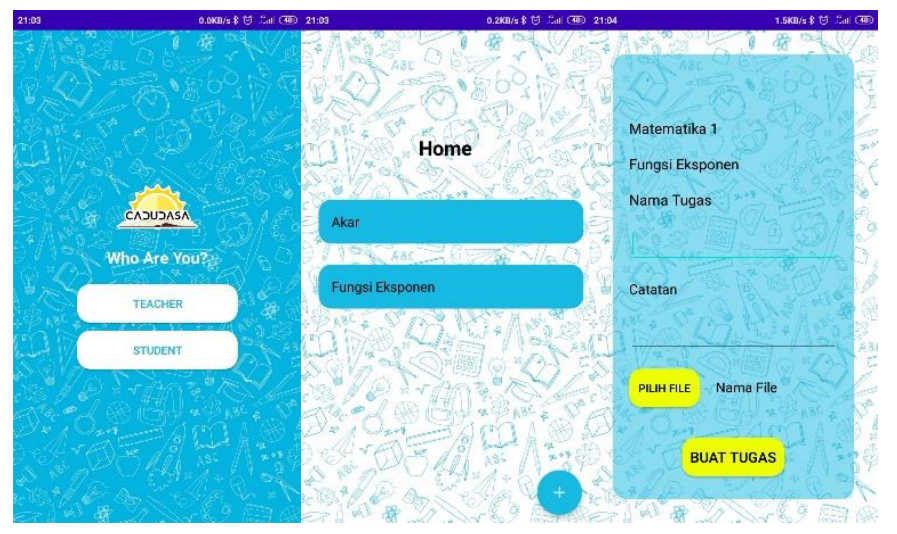

Figure 2. The Home Menu and Menu for creating assignments.

In this Android-based mobile learning application, the teacher can create a class by writing the class name and class code. The class code is determined by the teacher to make it easier for both teachers and students to remember the class code that has been set. Students can access the class by using the class code shown in Figure 3. 


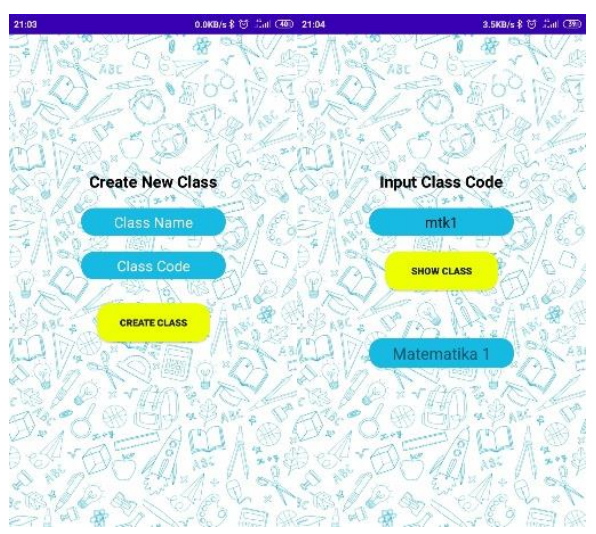

Figure 3. Class input display.

Furthermore, students can access teaching materials by downloading documents that have been uploaded by the teacher.

This Android-based mobile learning application was developed and designed using Adobe Experience Design software, CorelDRAW 2019, Android Studio, and assisted by the NoxPlayer android emulator. CorelDRAW was used to design the logo and background for the mobile learning application. The $\log 0$ of this androidbased mobile learning application is presented in Figure 4.

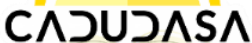

Figure 4. The logo of the android-based mobile learning application of Cadudasa.

The Cadudasa logo means that mobile learning media is an effort to create a bright future for education. The word Cadudasa is taken from Sanskrit which means brilliant.

\section{Develop}

At this stage, the activities performed were create the initial product of Cadudasa Mobile Learning Application, validation tests, product revisions, and product trials on a small scale. The process of making a product, using web-hosting and assisted by Android studio software to complete programming. Then the validation test of the Android-based mobile learning was performed by three experts who were deliberately selected from each field related to the Cadudasa mobile learning application, including 1 lecturer of Mathematics Education of UHAMKA, 1 Mathematics teacher at SMAN 106 of Jakarta, and 1 programmer of PT. Nityo Infotech. The results of the validation test were used to determine the eligibility of the experts which would then be tested on students (Apsari \& Rizki, 2018). The product was tested on 40 students in terms of several aspects, including graphic, button function, and media aspects (Apsari \& Rizki, 2018). The results of the validation of each expert are presented in Table 3.

Table 3 shows the assessment of expert validation on the Cadudasa mobile learning application media in terms of several aspects. First, the media efficiency aspect received a result of $86 \%$ with a very good category, Then, the button function aspect received a result of $83 \%$ with a good category, and the graphic aspect received a result of $83 \%$ with a good category. Overall, the quality of Cadudasa mobile learning media was assessed by 3 media experts with an average percentage of $84 \%$ in the good category. Based on these results, it can be said that the Cadudasa mobile learning application can be an alternative solution to several issues in the distance learning process. The solution is presented using media in the form of a mobile learning application (Khanghah et al., 2012; Kim et al., 2013).

The suggestions from experts on the Cadudasa mobile learning application as a whole included: (1) the addition of several buttons to make it easier to use applications such as the 
DOI: https://doi.org/10.24127/ajpm.v9i4.3138

back button. Application details should be clarified more so that users can use the application more easily. The application is good, but some improvements need to be carried out to make it even better, (2) There are some bugs in some cellphones. Backsound can be added when starting or while using the application.

Table 3. The test results of expert validation on the Cadudasa mobile learning application

\begin{tabular}{lccc}
\hline Items & $\underline{x}$ & $\%$ & Category \\
\hline Media Efficiency & & & \\
The application is easy to install and uninstall & 3,67 & $92 \%$ & Very Good \\
Creativity and innovation in the learning media & 3,67 & $92 \%$ & Very Good \\
Effective use of application storage space on the & 3,33 & $83 \%$ & Good \\
smartphone & 3,33 & $83 \%$ & Good \\
Ease of collecting assignments in the program & 3,00 & $75 \%$ & Fair \\
Ease of interacting with the program & 3,67 & $92 \%$ & Very Good \\
Ease of log in and log out of the program & 3,33 & $83 \%$ & Good \\
Ease of understanding button structure & 3,43 & $86 \%$ & Very Good \\
Total & & & \\
Button Function & 3,33 & $83 \%$ & Good \\
Ease of using the function of the file attachment & 3,33 & $83 \%$ & Good \\
button & 3,33 & $83 \%$ & Good \\
The precision of the button reaction & 3,33 & $83 \%$ & Good \\
Suitability of background selection & & & \\
Total & 3,00 & $75 \%$ & Fair \\
Graphic & 3,67 & $92 \%$ & Very Good \\
Suitability of size selection & 3,33 & $83 \%$ & Good \\
Suitability of size and font selection & 3,33 & $83 \%$ & Good \\
The attractiveness of the menu & 3,33 & $83 \%$ & Good \\
Suitability of color & 3,33 & $83 \%$ & Good \\
Suitability of image selection with menu & 3,38 & $\mathbf{8 4 \%}$ & Good \\
Total & & & \\
Subtotal & &
\end{tabular}

Furthermore, related to the validators' suggestion that (1) there is no button in the application view to smooth the use of the application, the application view was then being revised. Then, a direction sign was added to be used as a button which is useful to facilitate application use. In addition, some bugs were fixed in the application. The revision results can be seen in Figure 3.
Following the revision of the application, it was then tested on a small scale to 40 students. It was informed through a link and students could install the Cadudasa mobile learning application on an Android-based smartphone. They were also given a guide to use the application and then they responded to the instrument using Google form. 
DOI: https://doi.org/10.24127/ajpm.v9i4.3138

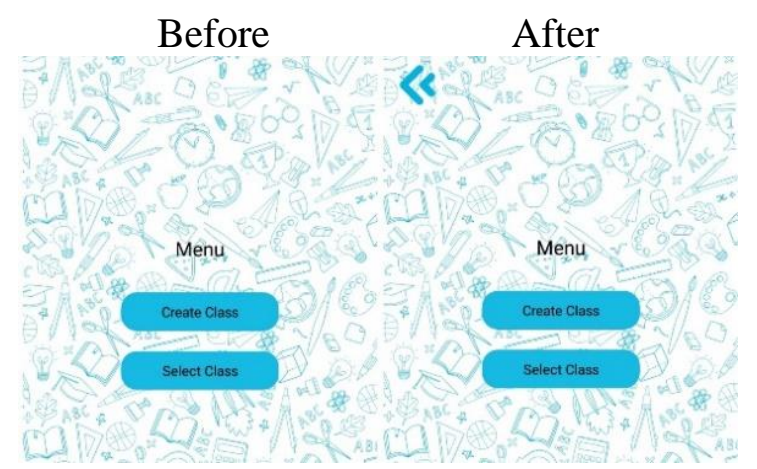

Figure 3. Revision by adding a button.

Table 4. The results of the feasibility test for the Cadudasa mobile learning application

\begin{tabular}{|c|c|c|c|}
\hline Items & $\underline{x}$ & $\%$ & Category \\
\hline \multicolumn{4}{|l|}{ Media Display } \\
\hline $\begin{array}{l}\text { The design of the Cadudasa mobile learning application } \\
\text { is attractive }\end{array}$ & 3,38 & $84 \%$ & Good \\
\hline Selection of the background is attractive & 3,68 & $92 \%$ & Very Good \\
\hline The layout of each button and function are easy to use & 3,38 & $84 \%$ & Good \\
\hline The choice of colors and fonts is clear and easy to read & 3,63 & $91 \%$ & Very Good \\
\hline $\begin{array}{l}\text { The language used in the application is easy to } \\
\text { understand }\end{array}$ & 3,58 & $89 \%$ & Very Good \\
\hline The display of content and assignments is easy to read & 3,30 & $83 \%$ & Good \\
\hline Total average & 3,49 & $87 \%$ & Very Good \\
\hline \multicolumn{4}{|l|}{ Button Functions \& Application } \\
\hline Function buttons can be used properly & 3,50 & $88 \%$ & Very Good \\
\hline The button structure is easy to understand & 3,48 & $87 \%$ & Very Good \\
\hline The image icon in the application is easy to understand & 3,35 & $86 \%$ & Very Good \\
\hline $\begin{array}{l}\text { The use of the attachment tool can make it easier to } \\
\text { collect tasks }\end{array}$ & 3,35 & $84 \%$ & Good \\
\hline Materials and assignments are easy to access & 3,38 & $84 \%$ & Good \\
\hline Applications are easy to install and uninstall & 3,55 & $89 \%$ & Very Good \\
\hline Total average & 3,43 & $86 \%$ & Very Good \\
\hline \multicolumn{4}{|l|}{ Application Usability } \\
\hline The application is easy to understand and use & 3,58 & $89 \%$ & Very Good \\
\hline $\begin{array}{l}\text { The application encourages me to be more active in } \\
\text { completing tasks }\end{array}$ & 3,25 & $81 \%$ & Good \\
\hline $\begin{array}{l}\text { The application encourages me to discuss with my } \\
\text { friends in completing assignments }\end{array}$ & 3,20 & $80 \%$ & Good \\
\hline The application can assist me in completing tasks & 3,40 & $85 \%$ & Good \\
\hline $\begin{array}{l}\text { The application motivates me to complete assignments } \\
\text { on time }\end{array}$ & 3,30 & $83 \%$ & Good \\
\hline Total average & 3,35 & $84 \%$ & Good \\
\hline Subtotal & 3,43 & $86 \%$ & Very Good \\
\hline
\end{tabular}

Table 4 shows the students' responses regarding the Cadudasa mobile learning media application in terms of several aspects. First, the aspect of media display received a result of $87 \%$ with a very good category. Then, the button function aspect received a result of $86 \%$ with a very good category. The 
last, the aspect of media functions received a result of $84 \%$ with a good category. Overall, the quality of Cadudasa mobile learning media as seen from the responses of 40 students received an average percentage of $86 \%$ in the very good category. This application was made based on students' needs and was used as an alternative distance learning solution. Therefore, it can be considered that the Cadudasa mobile learning application can be accepted by students and used properly. The Cadudasa application also encourages student motivation in learning. The system of the mobile learning application has made them more active in learning (Chen et al., 2016; Khanghah et al., 2012).

This research has produced an application that can be used for mobile learning. The name of that application is Cadudasa. The development of the mobile learning application provides good response in society because the majority of people utilize smartphones. They can easily access mobile learning applications anywhere and anytime. And based on the initial research, students need a medium that can help the distance learning process. By utilizing the widely used Android operating system with the simple and attractive design of the Cadudasa mobile learning application, students can be easily used it to work on their assignments and materials created by teachers to help the learning process for anywhere and anytime. This application still has much to do with further development to add several features, one of which is a feature for discussion.

This research is in line with Chung \& Khor's (2015) research on making mobile learning applications that can be accessed easily in real time distance learning, then research conducted by Rachmawati (2020) on the existence of learning materials and questions or tasks that can be accessed by students, the difference with this research is that the material and questions in this application can be updated as needed.

\section{CONCLUSION AND SUGGESTION}

The results of assessments performed by experts and trials carried out on students show that the Cadudasa mobile learning application is considered effective and feasible to be used as an alternative solution and can be used for efficient distance learning. This application can be utilized for assignments that can be done anytime and anywhere using the internet connection by the teacher and students.

The suggestion for the Cadudasa mobile learning application is that it needs to be tested on large-scale teachers and students to obtain responses and suggestions for the development of more optimal learning media. Besides, the Cadudasa mobile learning application needs to be developed and added with supporting features in other learning to make the process of distance learning easier. The last, it needs to be further developed so that it can be used in various operating systems.

\section{REFERENCES}

Al-Emran, M., Elsherif, H. M., \& Shaalan, K. (2016). Investigating attitudes towards the use of mobile learning in higher education. Computers in Human Behavior, 56, 93-102. https://doi.org/10.1016/j.chb.2015. 11.033

Al-hunaiyyan, A., Al-Sharhan, S., \& Alhajri, R. (2017). A New Mobile Learning Model in the Context of Smart Classroom Environment: 
DOI: https://doi.org/10.24127/ajpm.v9i4.3138

International Journal of Interactive Mobile Technologies (IJIM), 11(3), 39-56.

Alexander, A., Blair, K. P., Goldman, S., Jimenez, O., Nakaue, M., Pea, R., \& Russell, A. (2010). Go Math! How research anchors new mobile learning environments. 57-64. https://doi.org/10.1109/WMUTE.2 010.47

Amirullah, G., \& Susilo, S. (2018). Pengembangan Media Pembelajaran Interaktif Pada Konsep Monera Berbasis Smartphone Android. WACANA AKADEMIKA: Majalah Ilmiah Kependidikan, 2(1), 38. https://doi.org/10.30738/wa.v2i1.2 555

Apsari, P. N., \& Rizki, S. (2018). Media Pembelajaran Matematika Berbasis Android pada Materi Program Linear. Jurnal Aksioma Jurnal Pendidikan Matematika FKIP Univ. Muhammadiyah Metro, 7(1). https://doi.org/10.1299/jsmemag.1 21.1191_47

Astuti, C. C., Sari, H. M. K., \& Azizah, N. L. (2019). Perbandingan Efektifitas Proses Pembelajaran Menggunakan Metode E-Learning dan Konvensional. Proceedings of the ICECRS, 2(1), 35. https://doi.org/10.21070/picecrs.v2 i1.2395

Azka, A., \& Faradillah, A. (2020). PreService Teachers 'Perception s of Blended Learning on Mathematics Learning Based on Gender. 2(2), 121-129.

Başaran, S., \& Haruna, Y. (2017). Integrating FAHP and TOPSIS to evaluate mobile learning applications for mathematics. Procedia Computer Science, 120, 91-98. https://doi.org/10.1016/j.procs.201 7.11.214

Calimag, J. A. N. N. V, Miguel, P. A. G., Conde, R. S., \& Aquino, L. B. (2014). Ubiquitous Learning Environment Using Android Mobile Application. 2(2), 119-128.

Chen, C. H., Chou, Y. Y., \& Huang, C. Y. (2016). An Augmented-RealityBased Concept Map to Support Mobile Learning for Science. AsiaPacific Education Researcher, 25(4), 567-578. https://doi.org/10.1007/s40299016-0284-3

Chung, S. H., \& Khor, E. T. (2015). Development of interactive mobilelearning application in distance education via learning objects approach. Studies in Computational Intelligence, 598, 373-380. https://doi.org/10.1007/978-3-31916211-9_38

Crompton, H. (2017). Moving toward a mobile learning landscape: presenting a mlearning integration framework. Interactive Technology and Smart Education, 14(2), 97109. https://doi.org/10.1108/ITSE02-2017-0018

Erkollar, A., \& Oberer, B. J. (2012). Anytime . Everywhere . Mobile Learning in Higher Education: Creating a GIS Course Case Study : Integrating Mobile Learning Modules in Course. Computer Applications for Database, Education, and Ubiquitous Computing, 31-32.

Fessakis, G., Karta, P., \& Kozas, K. (2018). The Math Trail as a Learning Activity Model for MLearning Enhanced Realistic Mathematics Education: A Case Study in Primary Education. Teaching and Learning in a Digital 
DOI: https://doi.org/10.24127/ajpm.v9i4.3138

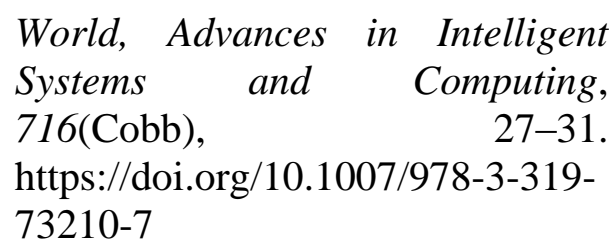

Grant, M. M. (2019). Difficulties in defining mobile learning: analysis, design characteristics, and implications. Educational Technology Research and Development, 67(2), 361-388. https://doi.org/10.1007/s11423018-09641-4Kumar, B. A., \& Mohite, P. (2018). Usability of mobile learning applications: a systematic literature review. Journal of Computers in Education, 5(1), $\quad 1-17$. https://doi.org/10.1007/s40692017-0093-6

Kumar, B. A., \& Mohite, P. (2018). Usability of mobile learning applications: a systematic literature review. Journal of Computers in Education, 5(1), 1-17. https://doi.org/10.1007/s40692017-0093-6

Hadi, W., \& Faradillah, A. (2019). The Algebraic Thinking Process in Solving Hots Questions Reviewed from Student Achievement Motivation. 10(2), 327-337.

Kearney, M., \& Maher, D. (2013). Mobile learning in maths teacher education: Using ipads to support pre-service teachers' rofessional development. Australian Educational Computing, 27(3), 7684.

Khanghah, M. F., Hajar, S., \& Halili, B. (2012). Design and Development of Mobile Learning Applications Using Drupal. Majalah Ilmiah Teknik Elektro, 9(1), 31-40. https://doi.org/10.24843/10.24843/ MITE
Kim, D., Rueckert, D., Kim, D., \& Seo, D. (2013). Students 'Perceptions Erceptions Rception of. 17(3), 5273.

Lamb, R. L., Annetta, L., \& Meldrum, J. (2012). Measuring science interest: rasch validation of the science interest survey. August 2011, 643668.

Lavin-Mera, P., Torrente, J., MorenoGer, P., Vallejo Pinto, J. A., \& Fernández-Manjón, B. (2010). Mobile Game Development for Multiple Devices in Education. International Journal of Emerging Technologies in Learning (IJET), 4(s2), 19-26. https://doi.org/10.3991/ijet.v4s2.91 0

Lu'ulilmaknun, U., \& Wutsqa, D. U. (2018). Efektivitas Media ELearning dengan Metode Guided Discovery Ditinjau dari Kemandirian Belajar Matematika Siswa. 7(3), 413-424.

Lynnette, C., \& Cabanban, G. (2013). Development of Mobile Learning Using Android Platform. International Journal of Information Technology \& Computer Science, 9(1), 98-106. http://ijitcs.com/volume 9_No_1/Christianne.pdf

Nasir, A. M., \& Nirfayanti. (2019). Efektivitas Media Pembelajaran Matematika Berbasis Mobile Learning Dalam Meningkatkan. 2.

Parvez, K., Khan, M., Iqbal, J., Tahir, M., Alghamdi, A., Alqarni, M., Alzaidi, A. A., \& Javaid, N. (2019). Measuring effectiveness of mobile application in learning basic mathematical concepts using sign language. Sustainability (Switzerland), 11(11), 1-20. https://doi.org/10.3390/su1111306 4 
DOI: https://doi.org/10.24127/ajpm.v9i4.3138

Rachmawati, Wijayanti, R., \& Kartika, E. D. (2020). Development Learning Media of Math-Cha to Support Vocational High School Revotalization. AKSIOMA: Jurnal Program Studi Pendidikan Matematika, 9(1), 133-146. https://doi.org/https://doi.org/10.24 127/ajpm.v9i1.2655

Rahayuningdewi, P. D., \& Faradillah, A. (2020). How does Problem-Solving Method Affect Students' SelfConfidence and Mathematical Understanding? 03(July), 165177.

https://doi.org/10.24042/ijsme.v3i2 .6640

Thiagarajan, S. (1974). Instructional development for training teachers of exceptional children: A sourcebook. In Indiana Univ., Bloomington. Center for Innovation in Teaching the Handicapped. (Vol. 14, Issue 1). https://doi.org/10.1016/00224405(76)90066-2 